Julia Boll

\title{
Between Homeland and Exile: Witnessing the Homo Sacer at the Heart of Hotel Medea
}

Abstract: Based on the Medea-myth, Zecora Ura Theatre's and Para Active's Brazilian-British co-production Hotel Medea (2010-2012) is an overnight promenade performance which actively involves the audience. It turns them into, alternatively, party guests, Medea's children, her closest friends, soldiers, and the focus group of Jason's political campaign. Medea herself, the archetypal refugee, represents the figure of the homo sacer, whom Giorgio Agamben describes as the one whose life is sacred, defined purely by her exclusion from the polis and stripped of all civil and human rights and of social and legal status. What is left is the bare life, the contact with which is taboo. The figure presents itself as an important parallel to the function of the scapegoat in tragedy and appears in contemporary theatre as a victim of war and conflict or as a person or group of people that have been legally ostracised from or have never been part of the community (such as asylum seekers, refugees, illegal immigrants, unlawful combatants, and displaced and stateless persons), by official decree turned into homines sacri. Agamben points out that Western politics is based on this simultaneous exclusion and inclusion of bare life into its legislation. Mostly, the bare life has remained invisible - the taboo status of the homo sacer demanding a shielding from the public eye. As the central political taboo on which, according to Agamben, Western society is founded, it has also remained the last taboo to be brought to the theatre. Drawing from Kelly Oliver's theory of an ethics based on witnessing, on enabling the other to form a subject's identity by not only allowing for a voice, but also by witnessing the other's act of speech, the theatre might be seen as the art form best suited to enable "witnessing beyond recognition." This essay discusses how Hotel Medea's unique inclusion and physical engagement of the audience allows for both the witnessing of and responding to the homo sacer, for an experience that goes far beyond spectatorship and successfully enables the audience to establish a relationship with the politically and socially excluded that might overcome the exclusion.

Keywords: Zecora Ura Theatre, Para Active, Hotel Medea, Giorgio Agamben, homo sacer, witnessing

Julia Boll: E-Mail: j.boll@uni-konstanz.de 
I saw Hotel Medea at Summerhall at the Edinburgh Festival in 2011. The show had already been through several London runs before; 2011 marked the project's tenth anniversary. It is a site-specific co-production between the Brazilian company Zecora Ura and the British company Para Active, conceived by Persis Jade Maravala and Jorge Lopes Ramos and devised by the companies. An overnight performance, it starts at midnight and ends at around six o'clock in the morning. It is separated into three parts: "Zero Hour Market," "Drylands" and "Feast of Dawn."

The show may be grouped under a heading that has recently become very popular in both theatre productions and in theatre research: "participatory theatre" or "immersive theatre," “a promenade play.” By describing my personal experience when attending one specific performance of the show in 2011, I will illustrate how strongly the audience is encouraged to participate, to give up their passivity as audience members and become something more, to contemplate their responsibility, and response-ability, to the Other, the figure Giorgio Agamben calls the homo sacer.

The full footage of one performance is available online, officially put up by the company (cf. Hotel Medea). The recording opens with a written statement: "Our intent was to experience a totally different type of contact with audiences who rose to the challenge of staying awake till dawn." The phrasing here is essential: by rising to this challenge, the audience members enter a pact, and the company could be assured that they would also be disposed to give something of themselves, too.

\section{“Zero Hour Market"}

The performance begins already with the audience's arrival. While the attendees of the London performance in 2010 were shipped over to the venue, an old wharf, the Edinburgh audience in 2011 did not experience this moment of embarking 'upon a journey,' since the old veterinary school at Summerhall is still in easy walking distance to the Old Town city centre. Nevertheless, in Edinburgh, too, patrons were greeted individually, they were given safety instructions and were shown a few dance steps that would come in handy later in the evening; it was pointed out to them that they could turn towards a member of the team at any time if they needed assistance. The team acted in a very reassuring way - the aim was not at all to alienate the audience, but to invite them in, to form bonds. In this respect, the experience was markedly different to Punchdrunk's Sleep No More (2011), for example, where part of the logic of the narrative hinged on the audience's disorientation, on them having to find their way by themselves through the labyrinthine McKittrick Hotel. 
At the beginning of "Zero Hour Market," we found ourselves in the middle of a bustling fair, where various hawkers attempted to show us a piece of the famed Golden Fleece (within the narrative framework of the show, this was forbidden: uniformed officials broke up the scenes again and again). We walked around in a slightly disoriented way until we understood we were supposed to behave like tourists at a market in a foreign country.

Soon after, the Argonauts arrive, Jason meets Medea for the first time, then loses her in the crowd, and in a classic re-enactment of a search for Cinderella, the audience stand in for Medea with the help of face masks bearing a picture of the actress who plays her. Jason and Medea fall in love very quickly - if not both voluntarily - then the wedding is arranged, and suddenly, we become very intimate with the characters and the actors who portray them: the men in the room, including the male part of the audience, prepare Jason for the ceremony, while all the women tend to Medea. This rather long sequence is important. With its soothing music and slow rhythmic movements, there is a strong ritual element to the situation, and at the same time, it feels very personal.

We throw rice at the wedding, and yet by this time in Hotel Medea, we are still not entirely sure what our role is in this performance. It feels a lot like a party we are part of an anonymous crowd, very much like the guests at a wedding in a small community one might attend without knowing bride or groom. For the audience member, who has long turned into a participant, there is also a moment of doubting the agreed framework of theatrical performance: it is around two o'clock in the morning; we might as well be out clubbing. On that particular night at the performance in Edinburgh which I attended, the company was very good at creating a party mood and the team could rely on an audience that was already quite used to the lines between theatre performance and party becoming increasingly blurred.

And yet, unwittingly, we are complicit with the Compère who leads us through this first part: on his orders, we will not let Jason and Medea leave with the Golden Fleece, but we take them by the shoulders and guide them back into the circle. We witness Medea freeing herself from the community that tries to keep her: by kissing them on the lips, she poisons members of her family one by one. But because we are distracted by music and dancing, it takes us a while to realise Medea's people are dropping like flies amongst us.

"Zero Hour Market" ends with Medea, Jason and the Argonauts leaving her mother country to go to Jason's homeland, where Jason embarks on his political career and Medea becomes an immigrant. She can never return home: she has burned all her boats.

It is important to remember where this story begins; where Medea comes from: seen in the terms of Classical Greece, Colchis is regarded as situated 'at the 
edge of the civilised world', where the Barbarians live. Medea is not considered civilised; she is a sorceress, her culture is viewed as primitive. While there is sympathy for her grief and anger at Jason's betrayal in most depictions of the myth, the extent of her revenge is often read as the act of a Barbarian: only a Barbarian would kill her own children.

In the development of his theory of the homo sacer, Agamben derives from Aristotle two terms for the state of living: $z o \bar{e}$ for the simple fact of living common to all living beings, animals, men and god alike, and bios, for "the form or way of living proper to an individual or a group," a life that has a certain quality and purpose to it (1). Bios means to be a citizen of a polis, to be able to participate in the shaping of society, in the cultural and political life of the community. If a person is cast out of their community, stripped of their civil rights and their social and legal status, they become the Roman homo sacer, the one "who may be killed and yet not sacrificed" (8; emphasis in the original). They are left in a state of bare life, the $z o \bar{e}$, the contact with which is taboo - and here, there is a parallel to the function of the scapegoat in tragedy, often the person who embodies the abject. Agamben stresses that the ancient meaning of the term sacer "before or beyond the religious [...] constitutes the first paradigm of the political realm of the West" (9). The boundaries of the polis, the centre of society, are marked by the exclusion of the homo sacer (7). In the second part of the show, Jason and Medea have entered the polis - Europe after the Schengen Agreement, if you will, or the Fortress West. But only one of them truly belongs.

\section{“Drylands"}

It is now about 2:30 in the morning, and after a short break, Hotel Medea's second chapter begins, "Drylands." We find ourselves in a different room, being prepared for a meeting with Jason, who aspires to win the upcoming election. We have been turned into a political focus group and have our picture taken with him. We become, willingly or unwillingly but certainly driven by curiosity, helpers in his political career, but suddenly, we are taken out of the viewing room by nursemaids dressed in white (and thus reminiscent of Brazilian Umbanda practitioners) who guide us into a large room where there are several bunk beds waiting. We don pyjamas, are tucked into bed by the nurses, who stroke our brows and tell us a gruesome bedtime story modelled on Jason and Medea's mythical journey from Colchis to Corinth. The audience's acceptance of their new role as the couple's children is noteworthy. From personal experience I can relate that most of the 'children' were completely focused on their respective 'nurse,' immediately willing to become part of the fictive family. Even considering the time of night and 


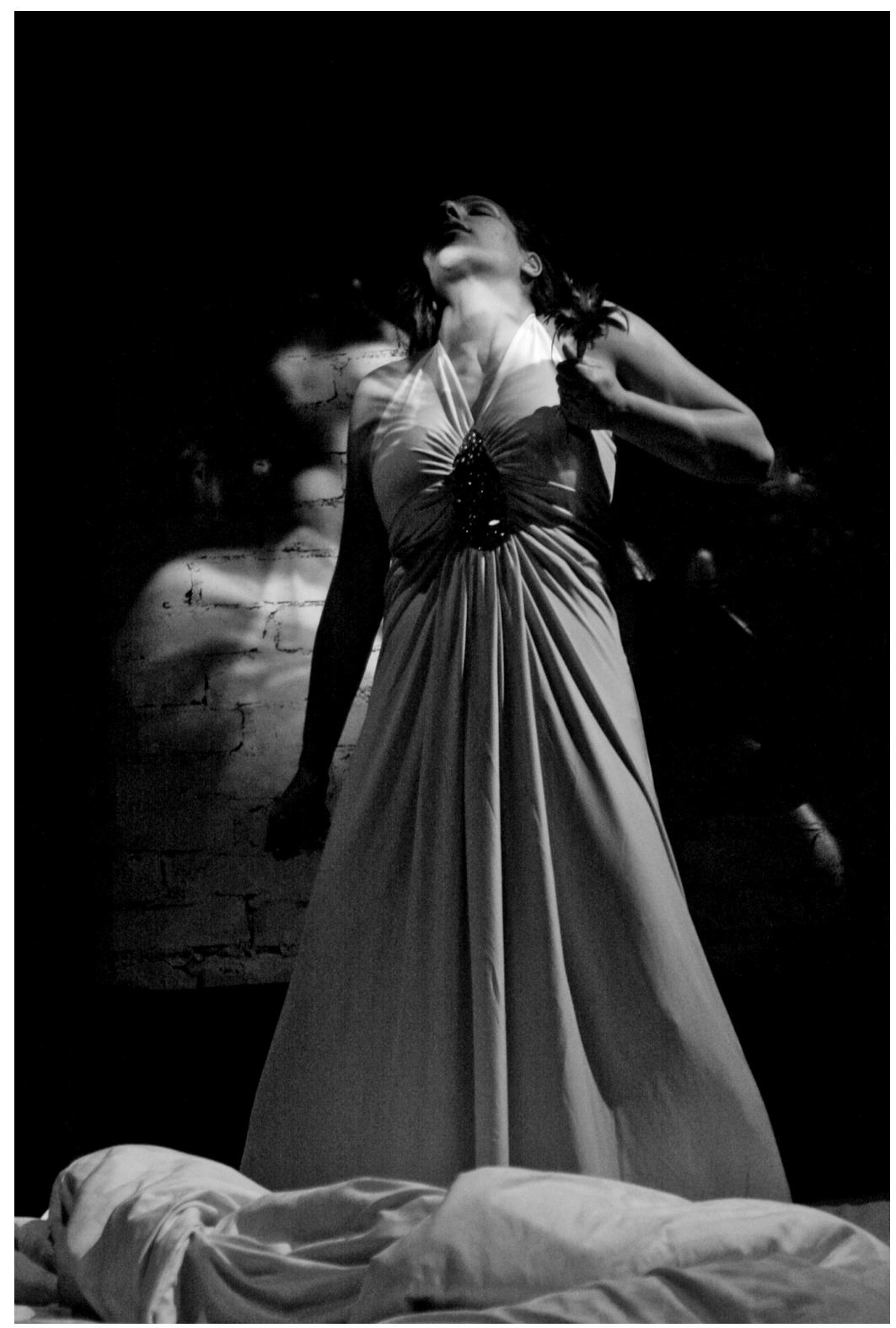

Abb. 1: Hotel Medea. Photo @ Ludovic des Cognets 2009.

consequently the assumable physical fatigue of most of the audience, this kind of immersion is remarkable. While the nurses try to make us sleep, the family drama unfolds in the middle of the room: Medea discovers that Jason has another 
woman, that she has been cast aside, and, howling in pain, she swears revenge. Jason's response is to have her citizen status withdrawn: he wants her to leave the country.

This is not the first instance in the play the subject of immigration and displacement is raised - of course, the whole first part, rooted as it is in Capoeira and Voodoo ritual, gestures, visually and by use of music and rhythm, towards the history of African slaves displaced to Brazil - and in order to further his political career, Jason has already used his wife's status as an immigrant in a political speech. But at this point in the production, it is made very clear that Jason's stand on immigration has changed - Medea is told in no uncertain terms that she has to leave, together with "all the other Barbarians like” her.

Through exclusion, the homo sacer is initially "situated at the margins of the political order," but the distinctions between included and excluded have shifted, Agamben argues, and those who are excluded from the modern polis signify a new kind of "living dead man, a new sacred man" (131). Those 'ousted' from the Fortress West, maybe even rendered stateless by denaturalisation decrees, may become refugees or asylum seekers and so find themselves outside the law, as homines sacri. The statelessness of refugees is not always to be accredited to the active stripping-away of rights. Zygmunt Bauman points out that "their statelessness is raised to an entirely new level" at a time of crumbling or failed states with no state authority to speak of and no body of state to which the refugees could be referred. They are thus truly "hors du nomos - outside law; not this or that law of this or that country, but law as such" (Bauman 37; emphasis in the original).

Agamben argues that the "concept of the refugee," and indeed the refugee as a "form of life," cannot be examined within a discussion of the concept of human rights. While he follows Hannah Arendt ${ }^{1}$ in stressing that the concept of human rights is intrinsically interlaced with the nation-state and that "the decline and crisis of the one necessarily implies the end of the other," he argues that the refugee

must be considered for what he is: nothing less than a limit concept that radically calls into question the fundamental categories of the nation-state, from the birth-nation to the mancitizen link, and that thereby makes it possible to clear the way for a long-overdue renewal of categories in the service of a politics in which bare life is no longer separated and excepted, either in the state order or in the figure of human rights. (134)

1 Agamben refers here to the fifth chapter (on refugees) of Arendt's study The Origins of Totalitarianism. 
The figure of the refugee, if made visible and consequently if acknowledged, is thus challenging and even threatening the very idea of the nation state as such. Bauman states that it is not even possible to properly grasp the concept of the refugee, as they are “ineffable ... Jacques Derrida's 'undecidables' made flesh [...] not only untouchables, but unthinkables. In a world filled to the brim with imagined communities, they are the unimaginables" (45; emphasis in the original).

\section{“Feast of Dawn"}

In the third part of Hotel Medea, "Feast of Dawn," the audience is led into a bar, Club Exile, where Medea performs her grief on stage, doubly exiled, in a way: from her homeland and from the house of love. In this scene, during which she invites audience members to listen to the sound of their hearts by use of a microphone, it becomes once more apparent how the performance manipulates the audience into responding to the whole show on an emotional rather than on an intellectual level.

Later at Club Exile, Medea also poisons the dress she will send to Jason's new bride. The bride burns to death in the dress, and in retaliation, Medea is brutally raped. This scene is quite unique in the way the event is communicated: rather than depicting the rape itself, Medea is carefully arranged by the nursemaids into a portrait of violation: to the sounds of choral music, she is lifted up and laid out onto a shopping cart filled with trash, her dress is torn up gently, her tights and underwear rolled down her legs, make-up is applied to depict extensive bruising and bleeding.

Kelly Oliver discusses witnessing as recognition of the other in an attempt to overcome the dichotomies between self and other, known and strange, and ultimately between those to whom empathy is extended and those to whom it will be denied. She proposes that witnessing the other, her joy and grief, possibly her oppression, should not only lead to recognition, but to something more active: it should evoke a sense of responsibility for and response-ability to the other. There is an obligation to witnessing, to testifying and listening to testimony, "because subjectivity and humanity are the result of witnessing," from which she concludes that subjectivity and humanity may be regarded as the result of "response-ability" (Oliver 90). Accepting the other's subjectivity, recognising the reality of others' experiences even if they are incomprehensible to us might allow us to establish "the conditions of address-ability and response-ability that make subjectivity and human experience possible and ultimately ethical” (106). 


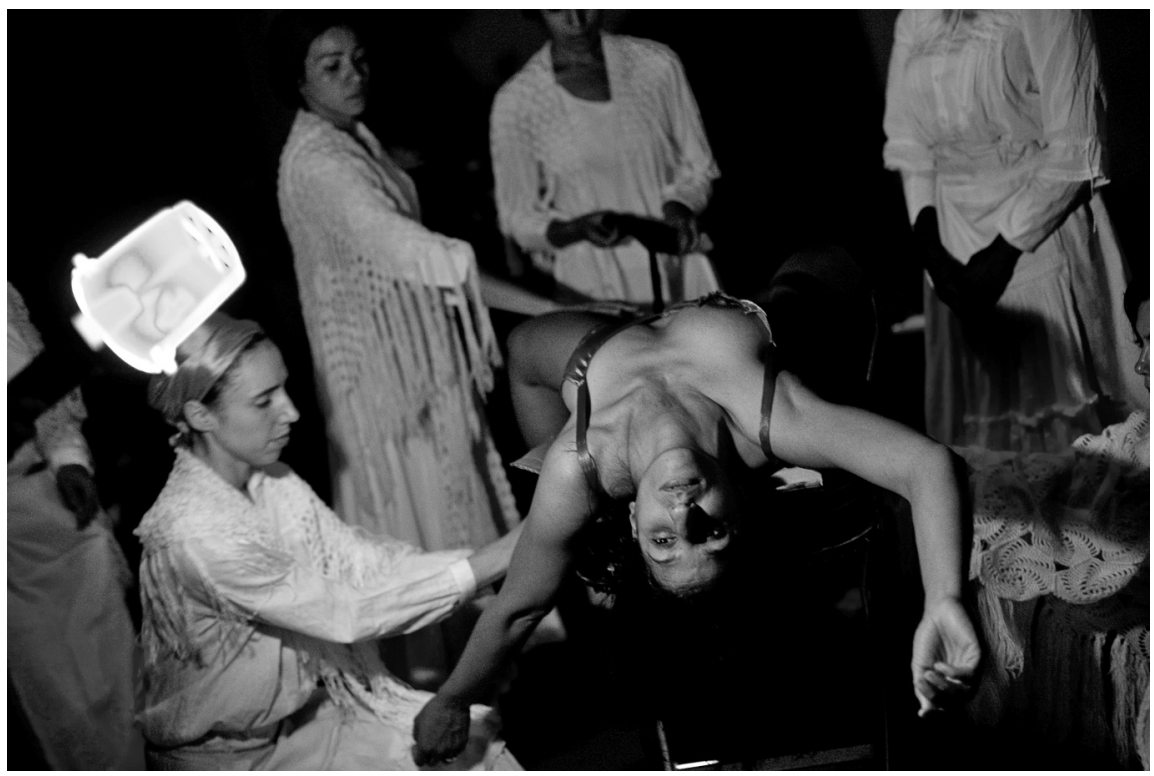

Abb. 2: Hotel Medea. Photo (C) Ludovic des Cognets 2010.

At the point when Medea is at her lowest, violated and discarded on a rubbish heap, the company treats the figure with utmost care and respect. We witness Medea, who has now truly become the homo sacer, cast out of society, homeless and uprooted, apparently stripped of civil protection and subject to preying news cameras. The cast, treating her so carefully, so reverently, help us recognise her sacred status: they treat her as something holy, as a person, they help us recognise her and go beyond recognition even, towards response-ability.

Interestingly, producer Jorge Lopes Ramos points out in an interview that the scene is in fact intended to be perceived as a 'faked' rape: "look at the delicate nature of the position," he says, "she has been placed carefully by her friends in this way. She wants to discredit Jason's political campaign" (Khan). In light of this statement, the whole analysis above seems to lose its base. Yet, I would like to argue that it is doubtful whether it truly matters that the depiction of the rape had originally been intended by the company to be recognised as a mere fabrication. Leaving aside the different ethical questions located in the realm of victimblaming which are raised by a company's deliberate decision to represent marital rape as a jilted wife's likely lie in order to discredit her spouse, what may have occurred here is in fact a realisation of Jacques Rancière's call for an emancipation of the spectator starting from "the principle of equality" that substitutes the power differences based on the knowledge-gap between performer and spectator 


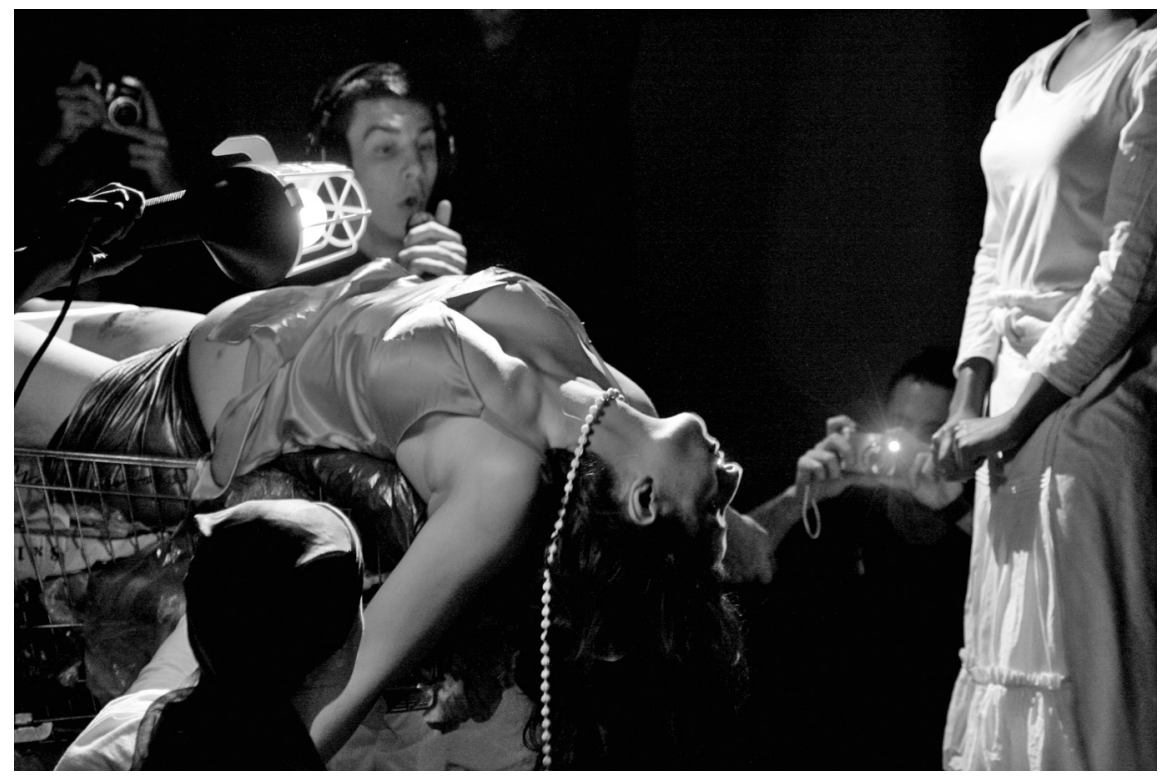

Abb. 3: Hotel Medea. Photo (C) Ludovic des Cognets 2009.

(Rancière 6). Speaking out against the "supposition that what will be felt or understood [by the spectator] will be what [theatre makers] have put in their own dramaturgy or performance" (6), Rancière defines the collective power of the spectators as "the power of translating in their own way what they are looking at [...], an unpredictable and irreducible play of associations and dissociations" (78). Recognising this power may have the potential of transforming the relationship between (active) performer and (passive) spectator. There is an echo of Nicolas Bourriaud's statement here, that "the aura of contemporary art is a free association," no longer restricted to "the hinter-world represented by the work, not in the form itself, but in front of it, within the temporary collective form that it produces by being put on show" (Bourriaud 61). ${ }^{2}$ The unique aura of the specific Edinburgh performance of Hotel Medea, which I attended in August 2011, is tied to an audience that "rose to the challenge of staying awake until dawn," during the exceptional state of a month-long theatre festival which had already attuned patrons to performances questioning the spectators' supposed neutrality, and to performances leaving their spectators much more leeway in their decoding and interpreting of the stories they witness.

2 I credit Wolfgang Funk with this line of thought. 
It is shortly after the very public - and publicised - incident of violation that Medea plans to murder her children in order to let Jason suffer as she has suffered. And at this point, the audience immersion reaches momentum: cast as the children again, the audience is taken off the main stage spaces and grouped into small sets, told to hide on the site. Of course, the play ends as the story of Medea always does: with two children dead.

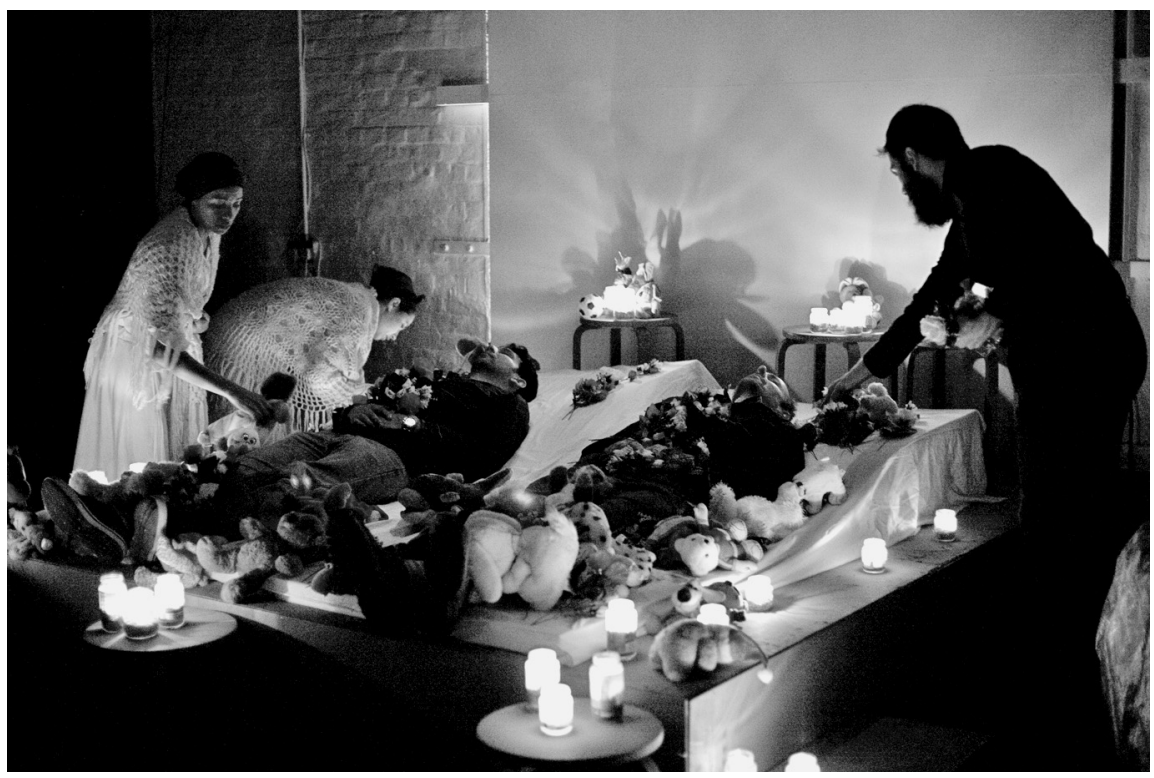

Abb. 4: Hotel Medea. Photo @ Ludovic des Cognets 2010.

By the time of the chase already, the audience is immensely tired as well: we have been worn out physically and emotionally by the performance. We realise after the show that the party was to loosen us up, to break our defences, to make sure we would build a connection to the actors that goes further than the roles they represent, that encompasses their physical presences: we have touched them, danced with them, cared for their bodies. Thus, when we arrive at the wake, with two members of the audience stretched out on biers in the middle of the room, when we are encouraged to decorate their bodies with flowers and stuffed animals, most of us have reached the point of full exhaustion, and to remain aloof and emotionally uninvolved has become nearly impossible. Medea is crouched at the side of the main stage area, and when audience members pass her, an interesting observation can be made: we touched her before, in "Zero Hour Market," but once we reach "Feast of Dawn," she should have become 
anathema, her transgressions too far, the taboo of a mother murdering her children too great.

We should not be able to touch her, should recoil, and yet, the level of audience empathy built up for this fictional character is extraordinary: echoing Marina Abramović's attempt to break down the separation between the performer and the spectator in 2010 by offering herself as an addressee for the patrons' quest for recognition, audience members approach the actress portraying Medea, look into her eyes, allow her to touch them, kiss them, even. Several begin to cry. In this show, the immersion did not happen purely as the result of a conscious decision on the part of the spectators. As audience members, we crossed over into the more active roles almost without noticing, through as one reviewer puts it, "authoritarian instruction or gentle coaxing" (Loxton).

Drawing from Oliver's theory of ethics based on witnessing, it is, I believe, possible to make a stand for the theatre as the art form which might be best suited to enable "witnessing beyond recognition." Theatre is an art of bodies witnessed by bodies, and the act of witnessing signifies a person attesting "to the truth of something that is or was present for them." Because witnesses are "something more than passive viewers," theatre audiences in their role as witnesses "are physically engaged by that which is present to them, to the extent that they might be physically possessed by it" (Shepherd 73). Through the physical presence of the bodies on stage the figure of the homo sacer, the bare life of which one is aware theoretically, in the form of statistics and reports, becomes once again connected to actual bodies. The visibility of the body, its very corporeality which we can ascertain by touching it, offers the opportunity to recognise it, to recognise Medea, the ultimate refugee, as a person, to establish a relationship with the excluded that might override the exclusion.

\section{Acknowledgment}

I thank photographer Ludovic des Cognets for his permission to reproduce pictures that he took of the production in 2009 and 2010. 


\section{Works Cited}

\section{Primary Literature}

Hotel Medea. By Zecora Ura and Para Active. Dir. Persis Jade Maravala and Jorge Lopes Ramos. Perf. Persis Jade Maravala. Arcola Theatre, London 2009-2010, Summerhall Fringe Venue, Edinburgh 2011. 15 Aug. 2013 〈www.medea.tv〉, 〈http://vimeo.com/hotelmedea〉.

Sleep No More. By Punchdrunk. Dir. Felix Barrett and Maxine Doyle. Beaufoy Building, London, 2003; American Repertory Theatre, Boston, 2009; The McKittrick Hotel, New York, 20112012. 15 Aug. 2013 <sleepnomorenyc.com>.

The Artist Is Present. By Marina Abramović. Museum of Modern Art, New York, 2010.

\section{Secondary Literature}

Agamben, Giorgio. Homo Sacer. Sovereign Power and Bare Life. Trans. Daniel Heller-Roazen. Stanford: Stanford UP, 1998.

Arendt, Hannah. The Origins of Totalitarianism. New York: Schocken Books, 1951.

Bauman, Zygmunt. Liquid Times. Living in an Age of Uncertainty. Cambridge: Polity, 2007.

Bourriaud, Nicolas. Relational Aesthetics. Trans. Simon Pleasance and Fronza Woods. Dijon: Les presses du réel, 2002.

Butler, Judith. Precarious Life. The Powers of Mourning and Violence. New York: Verso, 2004.

Khan, Naima. "Hotel Medea in Pictures." Spoonfed 9 July 2012. 1 Aug. $2013<$ spoonfed.co.uk/ spooners/spoonfed-theatre-team-8150/hotel-medea-in-pictures-7010/>.

Loxton, Howard. Rev. of Hotel Medea, by Zecora Ura and Para Active. British Theatre Guide July 2010. 1 Aug. 2013 <britishtheatreguide.info/reviews/hotelmedea-rev>.

Oliver, Kelly. Witnessing Beyond Recognition. Minneapolis: U of Minnesota P, 2001.

Rancière, Jacques. "The Emancipated Spectator." $5^{\text {th }}$ International Summer Academy of the Arts. Frankfurt am Main. 20 Aug. 2004. Keynote Address.

Shepherd, Simon. Theatre, Body and Pleasure. London: Routledge, 2006. 